\title{
Spatial distribution of Euphausiids (Euphausiacea) off Malpelo Island, Colombian Tropical Pacific
}

\author{
Marisol Rivera Gómez \& Alan Giraldo \\ Grupo de Investigación en Ciencias Oceanográficas. Facultad de Ciencias Naturales y Exactas, Universidad del Valle, Ciudad \\ Universitaria Meléndez. Calle 13 No.100-00 Cali, Colombia; marisol.rivera.gomez@correounivalle.edu.co, \\ oceanografia@correounivalle.edu.co, alan.giraldo@correounivalle.edu.co
}

Received 20-XII-2017. Corrected 31-VIII-2018. Accepted 07-XII-2018.

\begin{abstract}
Euphausiids migrate vertically in the water column as part of their diel cycle. These migrations make them a key element in the biological pump of the pelagic environment. In order to evaluate the vertical distribution of euphausiids around Malpelo Island (3.8 - 4.2 N \& 81.4 - $81.8 \mathrm{~W})$, we took stratified zooplankton samples (0-50, 50-100, and 100-150 m) during the Pacífico-ERFEN campaign in September 2012. A total of 10 species belonging to four genera were identified. Euphausia diomedeae was the most abundant species in the 0-50 and 100-150 m layers, whereas E. distinguenda was the most abundant species in the 50-100 m layer. Based on quasi-Poisson generalized linear distribution models we found that abundance in the 50-100 m layer was significantly higher than in the $100-150 \mathrm{~m}$ layer $(\mathrm{t}=3.05, \mathrm{p}<0.05)$. There were no significant differences associated with sampling hour (diurnal/nocturnal) $(\mathrm{t}=0.07, \mathrm{p}=0.94)$. We calculated a vertical distribution index (VDI) based on abundance, showed that euphausiid species were concentrated in the 50-100 $\mathrm{m}$ layer during day and night. Calyptopis larvae dominated in abundance at all depth layers, followed by furcilia larvae, juveniles, and adults. The abundance of the latter increased gradually from the most superficial layer to the deepest layer, whereas juveniles showed the opposite pattern. This is the first study to describe the taxonomic composition, and vertical and spatial distribution of euphausiids associated with Malpelo Island, Colombian Pacific.
\end{abstract}

Key words: nictemeral variation; Euphausia diomedeae; Euphausia distinguenda; Colombia; vertical migration.

Rivera Gómez, M., \& Giraldo, A. (2019). Spatial distribution of Euphausiids (Euphausiacea) off Malpelo Island, Colombian Tropical Pacific. Revista de Biología Tropical, 67(1), 243-253.

Malpelo Island is the only Colombian oceanic insular territory in the Pacific Ocean. It consists of the emergent part of a submarine mountain range called the Malpelo Dorsal. The island and the surrounding $26679 \mathrm{~km}^{2}$ area encompass a marine protected area in the category of Fauna and Flora Sanctuary (MMA, 1995; MADS, 2017) established in 1995. One of the main challenges in administrating and protecting a marine area is obtaining knowledge on the different taxonomic groups that inhabit it (Pomeroy, Parks, \& Watson, 2004). Therefore, efforts to establish trustworthy taxonomic information that would allow not only the quantification of biological diversity at a location, but also the identification of research themes required to strengthen management actions, are highly relevant.

Euphausiids comprise one of the zooplankton taxonomic groups with the least research effort thus far for the Colombian Pacific. Euphausiids are holoplanktonic crustaceans who carry out vertical migrations in the water column as part of their diel cycle. These migrations make them a key element in the biological pump of the pelagic environment 
worldwide (Werner \& Buchholz, 2013; Sogawa et al., 2016; Wiebe, Bucklin, Kaartvedt, Røstad, \& Blanco-Bercial, 2016). They also play an important role in marine trophic webs, as they represent a food source for several squid, fish, bird, and mammal species (Pauly, Trites, Capuli, \& Christensen, 1998; Estrada, Lutcavage, \& Thorrold, 2005; Zeidberg \& Robison, 2007; Hipfner, 2009).

Although research on this taxonomic group has been wide-ranging in the Eastern Pacific (see review in Fernández-Álamo \& Färber-Lorda, 2006), research has mostly been concentrated in some regions such as the California Current (e.g. Brinton \& Townsend, 2003; Ressler et al., 2005; Santora, Sydeman, Schroeder, Wells, \& Field, 2011), the Humboldt Current (e.g. Linacre \& Palma, 2004; González et al., 2009; Antezana, 2010), and the Mexican Tropical Pacific (e.g. Färber-Lorda, Trasviña, \& Cortés-Verdín, 2010; AmbrizArreola, Gómez-Gutiérrez, Franco-Gordo, Lavaniegos, \& Godínez-Domínguez, 2012). There have been few recent studies, except for the Mexican Tropical Pacific, where different aspects related to biological and ecological processes of this taxonomic group have been evaluated (López-Cortés, 1990; Färber-Lorda, Lavín, Zapatero, \& Robles, 1994; GómezGutiérrez et al., 2014). Studies on euphausiids in the remaining geographic area of the Eastern Tropical Pacific (ETP) were carried out in the 1960 's, and were focused on taxonomic identity and general spatial distribution patterns (Brinton, 1962; 1979), being scarce the studies realized in recent times.

For the ETP, which includes the Colombian Pacific, scientific studies on euphausiids have been carried out by Sameoto, Guglielmo \& Lewis (1987), who evaluated the temporal variation in vertical migration of euphausiids associated with the Costa Rica Dome, and by Azofeifa-Solano, Corrales-Ugalde, Castellanos-Osorio, \& Morales-Ramírez (2016), who carried out a taxonomic analysis of euphausiids associated with Cocos Island. Two studies have been published for the Colombian Pacific, one by Carvajal, Vergara \& López (2009) who analyzed the effects of El Niño and La Niña on four taxonomic groups at the genus level, including euphausiids, and one by López \& Medellín (2010), who described the taxonomic composition and spatial variation in abundance of euphausiids in superficial samples taken in the Colombian Pacific Basin in July 2006.

Considering the importance of euphausiids as an integral part and key component of oceanic food webs, the scarce information available on this taxonomic group in the Colombian Pacific, and the need to generate relevant technical information to strengthen management processes in the only protected oceanic area in the Colombian Pacific, the present study was carried out to identify taxonomically the euphausiids associated with the Malpelo Island protected area. Furthermore, the spatial variation in abundance in September 2012 is described, and the vertical migration pattern of dominant species is analyzed.

\section{MATERIALS AND METHODS}

Zooplankton samples used in this study were obtained during the ERFEN XV-CPC LI oceanographic campaign carried out in September 2012 aboard the ARC Providencia research vessel, ascribed to the Navy National Armed Forces and administered by the Maritime General Direction-DIMAR of Colombia. The oceanographic conditions at this location are strongly influenced by the Panama wind jet and by the intertropical convergence zone (Villegas \& Málikov, 2006; Villegas, Málikov \& Díaz, 2016). The $21{ }^{\circ} \mathrm{C}$ isotherm occurs between 30 and $35 \mathrm{~m}$ depth year-round, and the $15{ }^{\circ} \mathrm{C}$ isotherm occurs at $70 \mathrm{~m}$ depth during the first months of the year, and at over $125 \mathrm{~m}$ depth during the second semester of the year (Rodríguez-Rubio \& Giraldo, 2011). The sampling grid comprised 10 biological stations distributed around Malpelo Island (Fig. 1). Temperature and salinity were recorded at each station, at standard depths ranging from 0 to $200 \mathrm{~m}$. Vertical zooplankton samples were obtained using an oceanographic vertical net $0.3 \mathrm{~m}$ in diameter, $1.8 \mathrm{~m}$ in length, and of 250 


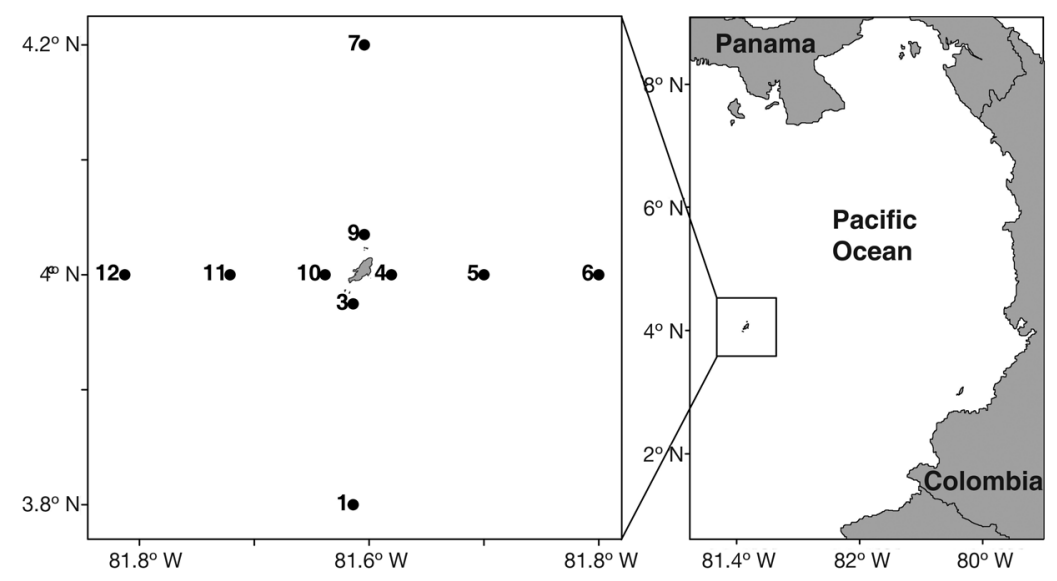

Fig. 1. Geographic location of the sample stations around Malpelo Island, Colombian Pacific, during the Oceanographic Campaign ERFEN XV - CPC LI in September 2012.

$\mu \mathrm{m}$ mesh size, including a General Oceanics Open-Close system at three depth layers: 0-50, 50-100, and 100-150 m. Zooplankton sampling was carried out only at the first two layers if depth at the station did not allow for deeper sampling. Samples were preserved in buffered formaldehyde at a final $4 \%$ concentration and transported to the laboratory of the Oceanographic Sciences Research Group of the Universidad del Valle.

Euphausiids present in the total sample were identified in the laboratory to the lowest taxonomic level possible using the guides by Boden, Johnson \& Brinton (1955), Baker, Boden, \& Brinton (1990), Gibbons Spiridonov, \& Tarling (1999) y Brinton, Ohman, Townsend, Knight, \& Bridgeman (2000). The recommendation of Brinton et al. (2000) regarding calyptopis and furcilia larvae of the group 1-A was followed; they were distributed proportionally according to the abundance of juveniles and adults of the species belonging to that classification (in this study, Euphausia eximia and Euphausia diomedeae, for which the proportions were 30 and $70 \%$, respectively). Counts were standardized (individuals $/ 1000 \mathrm{~m}^{3}$ ) based on the volume of filtered water estimated based on the distance travelled by the net $(50 \mathrm{~m})$ and the mouth area.
The richness estimators ICE, Chao-2, Bootstrapping and first order Jacknife, established by resampling $(\mathrm{n}=1000)$ (EstimateS $\mathrm{v}$ 8.0 ), were used to evaluate the effectiveness of sampling effort. The influence of layer depth and sampling time (day/night) on euphausiid abundance was estimated. As data did not meet the assumptions of normality and homogeneity of variances, generalized linear models with quasi-Poisson distribution, which had the best data adjustment, were used. These analyses were performed using the program $\mathrm{R}$.

Taking into account the total abundance at the $0-50 \mathrm{~m}$ vs. $50-100 \mathrm{~m}$, and $50-100 \mathrm{~m}$ vs. 100-150 m layers, the Vertical Distribution Index (VDI) was calculated as VDI $=\ln (\mathrm{n} 1$ / $\mathrm{n} 2$ ), where $\mathrm{n} 1$ is the abundance of species $i$ in the upper layer, and $\mathrm{n} 2$ is the abundance of species $i$ in the layer below. Finally, the spatial distribution in the abundance of each identified species was described, taking into account the three depth layers, using Surfer ${ }^{\circledR}$ v9 software.

\section{RESULTS}

The superficial temperature during the sampling period was $26.90 \pm 0.18{ }^{\circ} \mathrm{C}$ in the study area. The $21{ }^{\circ} \mathrm{C}$ isotherm was located at $50 \mathrm{~m}$ depth (Fig. 2). Superficial salinity was 

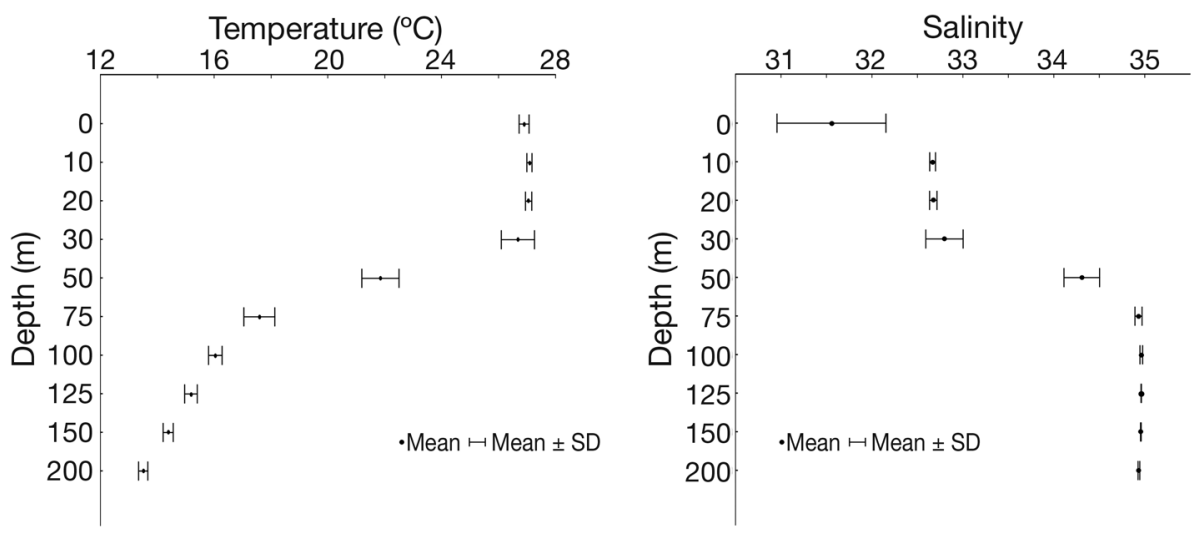

Fig. 2. Vertical variation of temperature $\left({ }^{\circ} \mathrm{C}\right)$ and salinity in the study area during September 2012 .

variable, with records ranging between 30.52 and 32.54. However, the salinity record stabilized at 32.50 between 10 and $30 \mathrm{~m}$ depth, and the halocline was located at $50 \mathrm{~m}$ (Fig. 2).

A total of 10 species belonging to four genera (Euphausia, Stylocheiron, Nematoscelis, and Nematobrachion) were identified (Table 1). The four estimators used to evaluate the effectiveness of sampling confirmed that the effort represented adequately the composition of the euphausiid assemblage in the study area (Fig. 3).

The 50-100 m layer had the highest average abundance, considering only the stations at which it was possible to evaluate all three layers (Fig. 4). The euphausiid abundance in the 50-100 m layer was significantly higher than in the $100-150 \mathrm{~m}$ layer $(\mathrm{p}<0.05)$, and, the abundance in the 50-100 m layer was higher than the 0-50 m layer, although differences were not significant $(\mathrm{p}=0.06)$. Besides, there

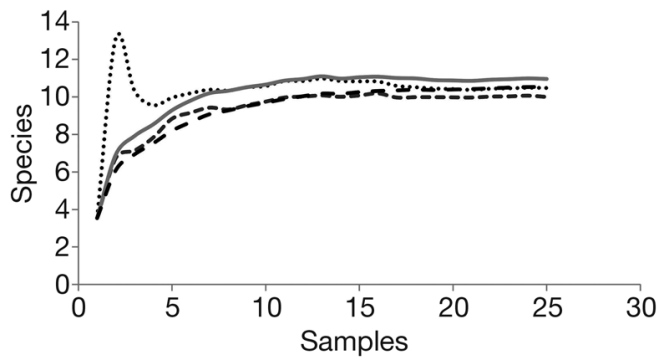

......ICE Mean - -- Chao 2 Mean — Jack 1 Mean - - Bootstrap Mean

Fig. 3. Species accumulation curve of euphausiids, considering all depth stratums surveyed around Malpelo Island, during September 2012.

TABLE 1

Species of euphausiids identified during September 2012 around Malpelo Island

\begin{tabular}{lccc}
\multicolumn{1}{c}{ Species } & \multicolumn{3}{c}{ Average abundance (ind. $1000 \mathrm{~m}^{-3}$ ) } \\
Euphausia distinguenda Hansen, 1911 & $0-50 \mathrm{~m}$ & $50-100 \mathrm{~m}$ & $100-150 \mathrm{~m}$ \\
Euphausia diomedeae Ortmann, 1894 & 396 & 594 & 340 \\
Euphausia eximia Hansen, 1911 & 430 & 357 & 413 \\
Euphausia tenera Hansen, 1905 & 136 & 209 & 153 \\
Stylocheiron carinatum G.O. Sars, 1883 & 141 & 170 & 0 \\
Nematoscelis gracilis Hansen, 1910 & 28 & 226 & 57 \\
Euphausia lamelligera Hansen, 1911 & 113 & 141 & 0 \\
Euphausia gibboides Ortmann, 1893 & 85 & 0 & 57 \\
Stylocheiron affine Hansen, 1910 & 28 & 28 & 0 \\
Nematobrachion flexipes Ortmann, 1893 & 0 & 57 & 57 \\
\hline
\end{tabular}




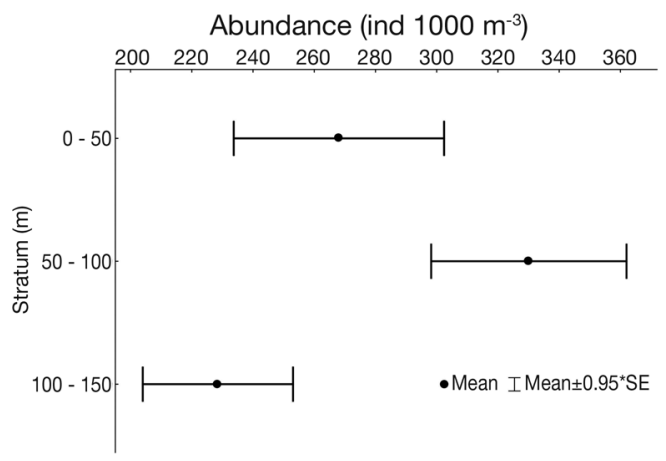

Fig. 4. Vertical distribution of the total abundance of euphausiids (ind. $1000 \mathrm{~m}^{-3}$ ) in the three depth stratums surveyed around Malpelo Island, during September 2012.

were no significant differences in abundance between the $0-50 \mathrm{~m}$ and $100-150 \mathrm{~m}$ layers $(\mathrm{p}=0.12)$. Sampling time did not affect significantly euphausiid abundance at the three depth layers $(\mathrm{p}=0.94)$.

Although defined vertical migration pattern with respect to time of day was not identified, the VDI suggested that euphausiid species were concentrated in the 50-100 m layer during night and day. Moreover, the VDI indicated that euphausiids were found in the 50-100 and $100-150 \mathrm{~m}$ layers independently of the time of day (Fig. 5).

None of the species was present at all sampling stations. However, the three most abundant species were widely distributed around the island at the three depth layers. Stylocheiron carinatum was the fifth most abundant species; it was present only at the western sector of the island in the 50-100 m layer and was not abundant in the 0-50 and 100-150 m layers (Fig. 6).

The dominant developmental phases at the three depth layers were calyptopis larvae, following by furcilia larvae, juveniles, and adults. Adults increased in abundance gradually from the upper layer down to the deepest layer, whereas juveniles presented the opposite pattern. Calyptopis as well as furcilia larvae were found in similar proportions at the three layers (Table 2).

TABLE 2

Percentage of contribution to the total of developmental phases by stratum

\begin{tabular}{lccc}
\multicolumn{1}{c}{ Phase } & $0-50 \mathrm{~m}$ & $50-100 \mathrm{~m}$ & $100-150 \mathrm{~m}$ \\
Calyptopis & 41.67 & 44.44 & 38.10 \\
Furcilia & 29.17 & 28.57 & 28.57 \\
Juvenil & 27.08 & 22.22 & 19.05 \\
Adultos & 2.08 & 4.76 & 14.29 \\
\hline
\end{tabular}

\section{DISCUSSION}

The ten species identified in this study have tropical and subtropical affinity (Brinton, 1962; Brinton et al., 2000) and are considered new records for Malpelo Island; however, all species have already been recorded for the Colombian Pacific (Rivera \& Giraldo, in press). Recently, Azofeifa-Solano et al. (2016) reported the presence of 13 euphausiid species around Cocos Island, Costa Rica, an oceanic
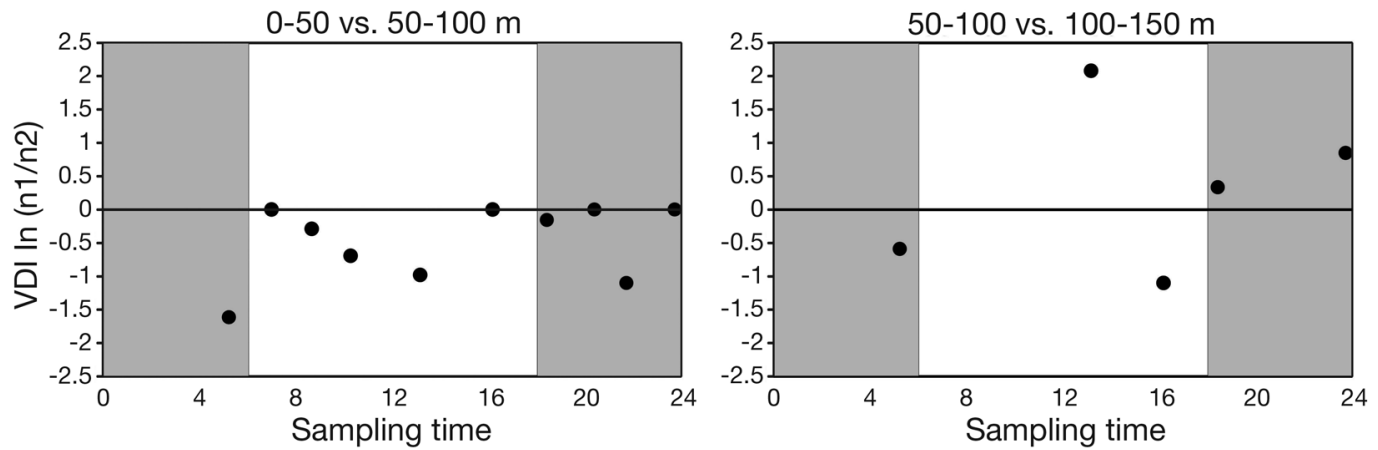

Fig. 5. Vertical Distribution Index (VDI) as a function of the sampling time of total euphausiid abundance around Malpelo Island. Shaded area indicates nocturnal hours. 


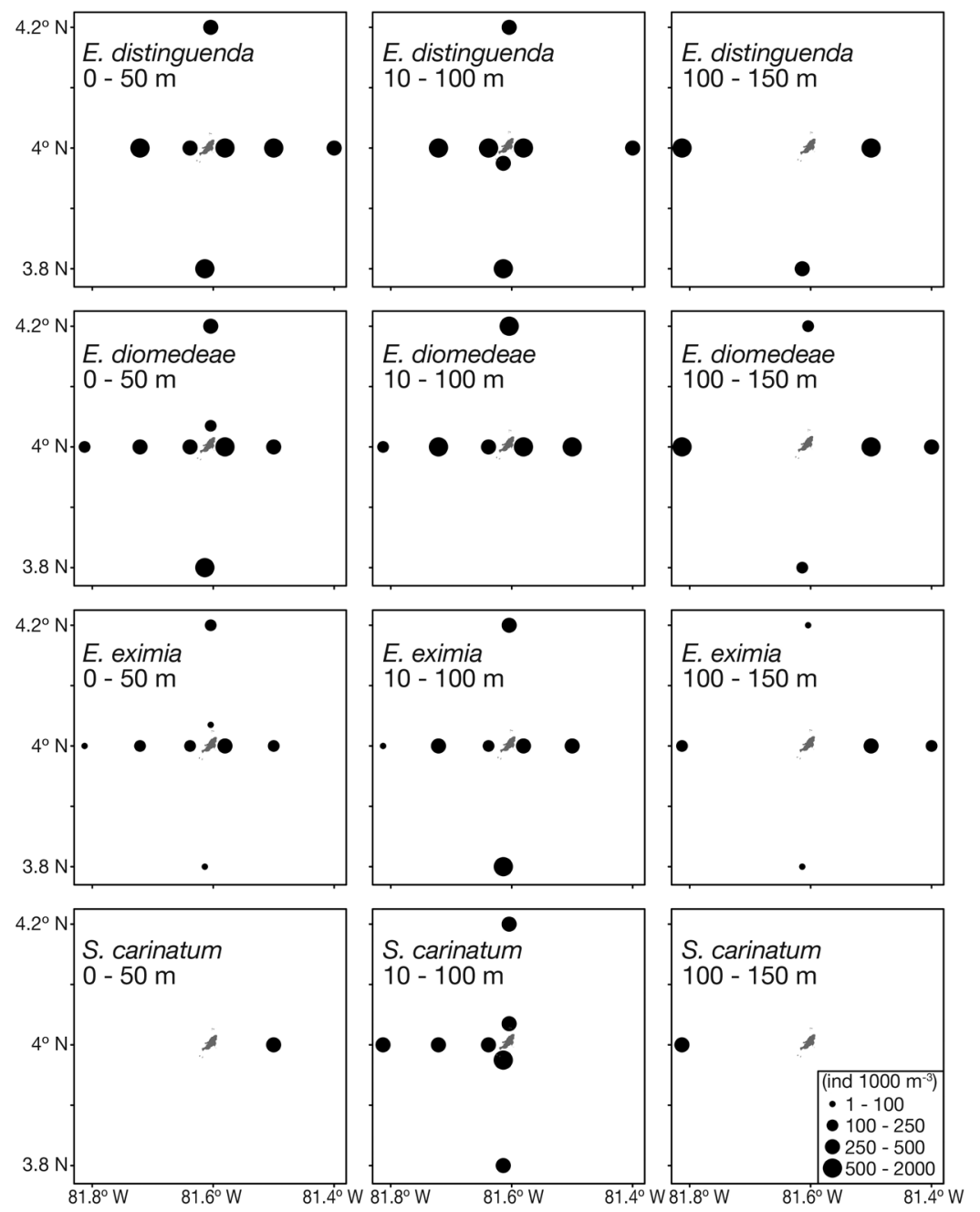

Fig. 6. Spatial distribution of the four more representative euphausiid species, for the three evaluated stratums, around Malpelo Island.

insular environment similar to Malpelo Island, with $100 \%$ of species recorded in Malpelo Island also recorded at Cocos Island. However, the specific richness of euphausiids at Malpelo Island was lower than that reported for other oceanic subtropical Eastern Pacific insular environments, such as the Juan Fernández Archipelago and the Desventuradas Islands in Chile, where 22 euphausiid species have been reported (Mujica \& Pavez, 2008). There is probably a confluence of species with tropical and subpolar affinity in subtropical regions, which would result in an increase in local specific richness, whereas in a tropical environment such as Malpelo Island we would only expect species with tropical affinity.

The abundant record of larval phases (calyptopis and furcilia) confirms the occurrence of active reproductive processes in this region. The type of net used during this study could have biased captures against adult specimens, because these organisms have greater swimming ability and their eyes are completely developed, which allows them to avoid nets (Mathew, 1988; Brierley, 1999; Everson, 2000). In the study carried out by Sameoto et 
al. (1987) in the Costa Rica Dome, the highest capture proportion was of adult individuals. In that study zooplankton captures were obtained with oblique tows, using a $1 \mathrm{~m}^{2}$ net at a speed of 2 knots, whereas during the present study zooplankton captures were obtained with vertical tows, using a $0.3 \mathrm{~m}^{2}$ area net at a speed of 0.5 knots. Despite this limitation, the sampling effort represented adequately the taxonomic composition of the euphausiid assemblage in the study area.

Most euphausiid species in Malpelo Island were located at the 50-100 m layer. A study by Andersen, Sardou \& Gasser (1997) reported that the highest euphausiid concentration occurred at between 0 and $150 \mathrm{~m}$ in eutrophic and mesotrophic sites, whereas in oligotrophic environments the trend was towards an almost uniform distribution between 0 and $700 \mathrm{~m}$ depth in the tropical Northeast Atlantic. In general, the depth range at which the highest abundance of euphausiids concentrates is valid for adults as well as for larvae; however, it should be noted that vertical migration also depends on the developmental phase (Escribano, Marin, \& Irribarren, 2000), so that juveniles and adults migrate more than larvae, which are probably always in the superficial layer.

The fact that there were no significant differences in euphausiid abundance between diurnal and nocturnal stations suggests that net evasion could have been equally effective during day and night, or that there was no significant evasion despite the evidence of net evasion by euphausiids in previous studies, established mainly based on differences in abundance between diurnal and nocturnal stations, with nocturnal stations presenting greater abundance (Brinton, 1967; Mathew, 1988). Sameoto et al. (1987) reported greater biomass and total abundance of euphausiids in the day compared with night in the Costa Rica Dome, and presence of rare species captured only at night, similarly to what occurred in this study for Malpelo Island, considering the case of Nematobrachion flexipes, which was only present at a nocturnal station in the 100-150 m layer.
There were adults of five species (E. diomedeae, E. distinguenda, E. tenera, N. gracilis, and $S$. carinatum) at the three depth layers only at the nocturnal stations, which coincides with the vertical distribution ranges of these species during nighttime hours, as it has been reported that $E$. diomedeae adults can be found at the surface and at $75 \mathrm{~m}$ depth during the night, whereas they are found at between 250 and $350 \mathrm{~m}$ during the day. E. distinguenda is found at between 300 and $400 \mathrm{~m}$ during the day, and above $50 \mathrm{~m}$ at night; E. tenera is found at between the surface and $140 \mathrm{~m}$ at night, and between 150 and $300 \mathrm{~m}$ during the day; $N$. gracilis has been reported to be between 100 and $300 \mathrm{~m}$ at night, and at between 300 and 500 $\mathrm{m}$ during the day; and $S$. carinatum remains between the surface and $140 \mathrm{~m}$ during the night (Brinton, 1962; Brinton et al., 2000).

Euphausia distinguenda was the most abundant species around Malpelo Island and the most abundant in the 50-100 m layer. The larval and juvenile phases of this species predominated and were present at the three depth layers during the day and night, despite Brinton et al. (2000) giving a range for adults of this species of 300 to $400 \mathrm{~m}$ during the day and above $50 \mathrm{~m}$ at night. Sameoto et al. (1987) found that $E$. distinguenda was the dominant species at two stations in the Costa Rica Dome, with greatest concentrations at between 250 and $450 \mathrm{~m}$ during the day and night, but with an abundance peak at night above the thermocline (10-50 m).

Roger (1971) reported Euphausia diomedeae as the most abundant species in the $0-100 \mathrm{~m}$ layer, representing $94 \%$ of the total species in that layer; he did not report it below $100 \mathrm{~m}$, which suggests that $E$. diomedeae did not cross the thermocline, which was at between 100 and $160 \mathrm{~m}$ depth in that study. In the present study, E. diomedeae was the most abundant species in the 0-50 m and 100-150 m layers around Malpelo Island, which suggests that contrary to Roger's study (1971) it crossed the thermocline, which has been reported at $70 \mathrm{~m}$ depth at the beginning of the year, and at $125 \mathrm{~m}$ during the second part of the year 
around Malpelo Island (Rodríguez-Rubio \& Giraldo, 2011).

The abundance of Euphausia eximia was intermediate, but this species was widely distributed around Malpelo Island at the three depth layers. Its abundance did not vary significantly between the three layers, but it was greatest at between 50 and $100 \mathrm{~m}$; this coincides with the study by Brinton et al. (2000), who reported E. eximia as a species migrating between the surface and $300 \mathrm{~m}$ depth. There were no adult organisms of this species, and juveniles were present only at nocturnal stations, similarly to what was reported by Andersen et al. (1997), with E. eximia present only at nocturnal stations in the tropical Atlantic.

Several authors have reported that Stylocheiron carinatum carries out short diel migrations (Brinton, 1967; Sameoto et al., 1987). For example, Brinton (1967) suggested that this species could carry out short migrations between the surface and $150 \mathrm{~m}$ during the day, and between the surface and $100 \mathrm{~m}$ at night. In the present study $S$. carinatum was captured mainly in the 50 to $100 \mathrm{~m}$ layer at diurnal as well as nocturnal stations, although it occurred at $0-50 \mathrm{~m}$ at one nocturnal station and at 100 $150 \mathrm{~m}$ at another nocturnal station, which suggests that this species could be found between the surface and $150 \mathrm{~m}$ during the day and night at Malpelo Island. This result is similar to that reported by Roger (1971) for the equatorial Pacific current system.

Stylocheiron affine was collected only in the 50 to $100 \mathrm{~m}$ layer. Despite the fact that it was not found at the deepest layer, the fact that it was not found between the surface and $50 \mathrm{~m}$ suggests that this species does not occur in the upper layer. Brinton et al. (2000) reported it as a species found above the thermocline, and suggested that it is present between the surface and the thermocline. However, results from the present study coincide with Roger (1971), who reported it at between 50 and $200 \mathrm{~m}$, Hirota (1987) who recorded this species at around 100 $\mathrm{m}$ in the day and at between 50 and $300 \mathrm{~m}$ at night, and Youngbluth (1975), who reported it at between 50 and $250 \mathrm{~m}$ depth.
In conclusion, the present research study represents the first euphausiid record for Malpelo Island, Colombia. We described the spatial variation in abundance of this important taxonomic group in an insular location of the Eastern Tropical Pacific and established vertical variation patterns of the different species recorded at this location. It is necessary to direct research efforts towards quantifying the role of these organisms in energy transfer processes of the pelagic web of the oceanic environment of the Colombian Pacific, as well as evaluating their response to mesoscale oceanographic forcing such as El Niño/La Niña.

Ethical statement: authors declare that they all agree with this publication and made significant contributions; that there is no conflict of interest of any kind; and that we followed all pertinent ethical and legal procedures and requirements. A signed document has been filed in the journal archives.

\section{ACKNOWLEDGMENTS}

We thank Vanessa Izquierdo for her valuable help during zooplankton sampling. We thank the B.O. ARC Providencia crew for their unconditional support during the field phase of this investigation. We thank the General Maritime Direction (DIMAR) and the Center for Oceanographic and Hydrographic Research of the Pacific (CCCP) of the National Navy for their invitation to participate in sampling and analysis of the zooplankton component during the Oceanographic Campaign Pacífico LI - ERFEN XV and for carrying out the discrete record of temperature and salinity. This study was co-financed by DIMAR, CCCP, the Universidad del Valle, and the Programa Jóvenes Investigadores e Innovadores Virginia Gutiérrez de Pineda Convocatoria 617-2013, which benefitted the first author of this paper.

\section{RESUMEN}

Distribución espacial de Eufáusidos (Euphausiacea) en la Isla Malpelo, Pacífico Tropical de Colombia. 
Los eufáusidos son organismos que realizan migraciones verticales en la columna de agua como parte de un ciclo nictemeral, estas migraciones los convierten en un elemento clave del ambiente pelágico. Con el propósito de evaluar la distribución vertical de los eufáusidos alrededor de la isla Malpelo (3.8-4.2 N \& 81.4-81.8 W), se tomaron muestras estratificadas (0-50, 50-100 y 100-150 m) de zooplancton durante la campaña Pacífico-ERFEN de septiembre 2012. Se identificaron un total de 10 especies pertenecientes a cuatro géneros, siendo Euphausia diomedeae la especie más abundante en los estratos 0-50 y 100-150 m, mientras que $E$. distinguenda fue la especie más abundante en el estrato de 50-100 m. Con base en modelos lineales generalizados con distribución quasipoisson se encontró que la abundancia del estrato de 50-100 m fue significativamente mayor que la del estrato de $100-150 \mathrm{~m}(\mathrm{t}=3.05, \mathrm{p}$ $<0.05$ ), sin embargo no se detectaron diferencias significativas asociadas con la hora del muestreo (diurna/nocturna) $(\mathrm{t}=0.07, \mathrm{p}=0.94)$. Con base en la abundancia se construyó un índice de distribución vertical (IDV) encontrando que las especies de eufáusidos estuvieron concentradas en el estrato de 50-100 m durante el día y durante la noche. En los tres estratos de profundidad dominaron en abundancia las larvas calyptopis, seguido de las larvas furcilias, los juveniles y los adultos. Estos últimos incrementaron su abundancia gradualmente desde el estrato más superficial hasta el más profundo mientras que los juveniles tuvieron un patrón opuesto. Este es el primer trabajo que describe la composición taxonómica y distribución vertical y espacial de los eufáusidos asociados a la isla Malpelo, Pacífico colombiano.

Palabras clave: variación nictemeral; Euphausia diomedeae; Euphausia distinguenda; Colombia; migración vertical.

\section{REFERENCES}

Ambriz-Arreola, I., Gómez-Gutiérrez, J., Franco-Gordo, M. C., Lavaniegos, B. E., \& Godínez-Domínguez, E. (2012). Influence of coastal upwelling-downwelling variability on tropical euphausiid abundance and community structure in the inshore Mexican central Pacific. Marine Ecology Progress Series, 451, 119-136.

Andersen, V., Sardou, J., \& Gasser, B. (1997). Macroplankton and micronekton in the northeast tropical Atlantic: abundance, community composition and vertical distribution in relation to different trophic environments. Deep Sea Research I, 44(2) 193-222.

Antezana, T. (2010). Euphausia mucronata: A keystone herbivore and prey of the Humboldt Current System. Deep Sea Research Part II: Topical Studies in Oceanography, 57(7), 652-662.

Azofeifa-Solano, J. C., Corrales-Ugalde, M., Castellanos-Osorio, I., \& Morales-Ramírez, Á. (2016).
Euphausiids (Crustacea: Euphausiacea) from a hotspot of marine biodiversity, Isla del Coco, Costa Rica, Eastern Tropical Pacific. Revista de Biología Tropical, 64(1), S221-S230.

Baker, A. de C., Boden, B. P., \& Brinton, E. (1990). A Practical Guide to the Euphausiids of the World. British Museum (Natural History). London: Cromwell Road.

Boden, B. P., Johnson, M. W., \& Brinton, E. (1955). The Euphausiacea (Crustacea) of the North Pacific. United States of America: University of California Press.

Brierley, A. (1999). A comparison of Antarctic euphausiids sampled by net and from geothermally heated waters: insights into sampling bias. Polar Biology, 22, 109-114.

Brinton, E. (1962). The distribution of Pacific euphausiids. Bulletin of the Scripps Institution of Oceanography of the University of California, 8(2), 21-270.

Brinton, E. (1967). Vertical migration and avoidance capability of euphausiids in the California Current. Limnology and Oceanography, 12(3), 451-483.

Brinton, E. (1979). Parameters relating to the distributions of planktonic organisms, especially Euphausiids in the eastern tropical Pacific. Progress in Oceanography, 8, 125-189.

Brinton, E., Ohman. M. D., Townsend, A., Knight, M., \& Bridgeman, A. L. (2000). Euphausiids of the World Ocean, CD-ROM. Windows version 1.0 ed. (2000). UNESCO Publishing and ETI (Expert Center for Taxonomic Identification, University of Amsterdam).

Brinton, E., \& Townsend, A. (2003). Decadal variability in abundances of the dominant euphausiid species in southern sectors of the California Current. Deep Sea Research Part II: Topical Studies in Oceanography, 50(14), 2449-2472.

Carvajal, L., Vergara, C., \& López, R. (2009). Chaetognatha, Thaliacea, Euphausiacea and Pelagic Polychaeta in the Colombian Pacific Ocean, during two periods in 1996 (La Niña) and two periods in 1997 (El Niño). Revista Facultad de Ciencias Básicas, 5(1), 172-185.

Escribano, R., Marin, V., \& Irribarren, C. (2000). Distribution of Euphausia mucronata at the upwelling area of Peninsula Mejillones, northern Chile: the influence of the oxygen minimum layer. Scientia Marina, 64(1), 69-77.

Estrada, J. A., Lutcavage, M., \& Thorrold, S. R. (2005). Diet and trophic position of Atlantic bluefin tuna (Thunnus thynnus) inferred from stable carbon and nitrogen isotope analysis. Marine Biology, 147(1), $37-45$.

Everson, I. (2000). Krill: biology, ecology and fisheries. Oxford: Blackwell Science. 
Färber-Lorda, J., Lavín, M. F., Zapatero, M. A., \& Robles, J. M. (1994). Distribution and abundance of euphausiids in the Gulf of Tehuantepec during wind forcing. Deep-Sea Research I, 41, 359-367.

Färber-Lorda, J., Trasviña, A., \& Cortés-Verdín, P. (2010). Summer distribution of euphausiids in the entrance of the Sea of Cortés in relation to hydrography. DeepSea Research II, 57, 631-641.

Fernández-Álamo, M. A., \& Färber-Lorda, J. (2006). Zooplankton and the oceanography of the eastern tropical Pacific: a review. Progress in Oceanography, 69(2), 318-359.

Gibbons, M., Spiridonov, V., \& Tarling, G. (1999). Euphausiacea. In D. Boltovskoy (Ed.), South Atlantic zooplankton (pp. 1241-1279). Holanda: Backhuys Publishers.

Gómez-Gutiérrez, J., Funes-Rodríguez, R., Arroyo-Ramírez, K., Sánchez-Ortíz, C. A., Beltrán-Castro, J. R., Hernández-Trujillo, S., Palomares-García, R., Aburto-Oropeza, O., \& Ezcurra, E. (2014). Oceanographic mechanisms that possibly explain dominance of neritic tropical zooplankton species assemblages around the Islas Marías Archipelago, Mexico. Latin American Journal of Aquatic Research, 42, 1009-1034.

González, H. E., Daneri, G., Iriarte, J. L., Yannicelli, B., Menschel, E., Barría, C., Pantoja, S., \& Lizárraga, L. (2009). Carbon fluxes within the epipelagic zone of the Humboldt Current System off Chile: The significance of euphausiids and diatoms as key functional groups for the biological pump. Progress in Oceanography, 83(1), 217-227.

Hipfner, J. M. (2009). Euphausiids in the diet of a North Pacific seabird: annual and seasonal variation and the role of ocean climate. Marine Ecology Progress Series, 390, 277-289.

Hirota, Y. (1987). Vertical distribution of euphausiids in the western Pacific ocean and the eastern Indian ocean. Bulletin of Japan Sea Regional Fisheries Research Laboratory, 37, 175-224.

Linacre, L., \& Palma, S. (2004). Variabilidad espacio-temporal de los eufáusidos frente a la costa de Concepción, Chile. Investigaciones Marinas, 32(1), 19-32.

López-Cortés, D. J. (1990). Distribución de la familia Euphausiidae (Euphausiacea: Crustacea) en el Golfo de Tehuantepec, México. Revista de Biología Tropical, 38, 21-28.

López, R., \& Medellín, J. (2010). Distribución de eufausiáceos (Crustacea: Malacostraca) en el océano Pacífico colombiano durante el periodo 02 a 27 de septiembre de 2005. Revista de la Facultad de Ciencias Básicas, 6(2), 240-255.

Mathew, K. J. (1988). Net avoidance behaviour among larval, juvenile and adult euphausiids. Journal of the Marine Biological Association of India, 30(1-2), 93-98.

MMA. (1995). Resolución 1292 de 1995, Ministerio del Medio Ambiente, República de Colombia.

MADS. (2017). Resolución 1907 de 2017, Ministerio de Ambiente y Desarrollo Sostenible, República de Colombia.

Mujica, A., \& Pavez, C. (2008). Eufáusidos de la zona central de Chile, archipiélago Juan Fernández e islas Desventuradas. Latin American Journal of Aquatic Research, 36(2), 283-300.

Pauly, D., Trites, A. W., Capuli, E., \& Christensen, V. (1998). Diet composition and trophic levels of marine mammals. ICES Journal of Marine Science: Journal $d u$ Conseil, 55(3), 467-481.

Pomeroy, R. S., Parks, J. E., \& Watson, L. M. (2004). How is your MPA doing?: a guidebook of natural and social indicators for evaluating marine protected area management effectiveness. Margate, UK: Thanet Press Ltd.

Ressler, P. H., Brodeur, R. D., Peterson, W. T., Pierce, S. D., Vance, P. M., Røstad, A., \& Barth, J. A. (2005). The spatial distribution of euphausiid aggregations in the Northern California Current during August 2000. Deep Sea Research Part II: Topical Studies in Oceanography, 52(1), 89-108.

Rivera, M., \& Giraldo, A. (2018). Eufáusidos (Arthropoda: Malacostraca: Euphausiacea) de la cuenca Pacífica colombiana. Biota Colombiana. En prensa.

Rodríguez-Rubio, E., \& Giraldo, A. (2011). Características oceanográficas en la isla Malpelo y su relación con la cuenca oceánica del Pacífico colombiano. Boletín de Investigaciones Marinas y Costeras, 40, 19-32.

Roger, C. (1971). Distribution verticale des euphausiacés (crustacés) dans les courants équatoriaux de l'Océan Pacifique. International Journal on Life in Oceans and Coastal Waters, 10(2), 134-144.

Sameoto, D., Guglielmo, L., \& Lewis, M. K. (1987). Day/ night vertical distribution of euphausiids in the eastern tropical Pacific. Marine Biology, 96, 235-245.

Santora, J. A., Sydeman, W. J., Schroeder, I. D., Wells, B. K., \& Field, J. C. (2011). Mesoscale structure and oceanographic determinants of krill hotspots in the California Current: Implications for trophic transfer and conservation. Progress in Oceanography, 91(4), 397-409.

Sogawa, S., Sugisaki, H., Saito, H., Okazaki, Y., Ono, T., Shimode, S., \& Kikuchi, T. (2016). Seasonal and regional change in vertical distribution and diel vertical migration of four euphausiid species (Euphausia pacifica, Thysanoessa inspinata, T. longipes, and Tessarabrachion oculatum) in the northwestern Pacific. 
Deep Sea Research Part I: Oceanographic Research Papers, 109, 1-9.

Villegas, N. L., \& Málikov, I. (2006). "Modelación de la estructura dinámica de las aguas de la cuenca del Pacífico colombiano". Boletín Científico CCCP, 13, 97-114.

Villegas, N., Málikov, I., \& Díaz, D. (2016). Variabilidad mensual de la velocidad de surgencia y clorofila a en la región del Panama Bight. Revista Mutis, 6(2), 82-94.

Werner, T., \& Buchholz, F. (2013). Diel vertical migration behaviour in Euphausiids of the northern Benguela current: seasonal adaptations to food availability and strong gradients of temperature and oxygen. Journal of Plankton Research, 35(4), 792-812.

Wiebe, P. H., Bucklin, A., Kaartvedt, S., Røstad, A., \& Blanco-Bercial, L. (2016). Vertical distribution and migration of euphausiid species in the Red Sea. Journal of Plankton Research, 38(4), 888-903.

Youngbluth, M. (1975). The vertical distribution and diel migration of euphausiids in the central waters of eastern South Pacific. Deep-Sea Research, 22, 519-536.

Zeidberg, L. D., \& Robison, B. H. (2007). Invasive range expansion by the Humboldt squid, Dosidicus gigas, in the eastern North Pacific. Proceedings of the National Academy of Sciences, 104(31), 12948-12950. 